\title{
Perioperative Cerebrospinal Fluid Diversion Utilizing Lumbar Drains in Transsphenoidal Surgery
}

Henry Jung, Aatman Shah and Abdulrazag Ajlan*

Neurosurgery Department, Stanford University, Stanford, CA, USA

\begin{abstract}
Lumbar drains (LD) for cerebrospinal fluid (CSF) diversion are commonly used in pituitary surgery. CSF perioperative diversion can be utilized as a prophylactic measure and/or as a first line treatment for CSF rhinorrhea following transsphenoidal pituitary surgery. In theory, lumbar drainage can prevent and/or treat CSF leaks and may preclude reexploration surgery. We performed a literature review to study the value of LDs in decreasing the postoperative CSF leak rates in transsphenoidal surgery and the reported perioperative complications in relation to perioperative LD insertion. We included studies with more than 100 patients, in the period from 2000 to 2012 . The overall incidence of postoperative CSF rhinorrhea was $1.7 \%$. Out of 6,401 patients, 385 patients $(6 \%)$ received LD to prevent postoperative CSF leak or as a therapeutic intervention. Complications with the use of LDs are not common; however, LDs can increase the length of hospitalization. The most common reported complications are headaches and patient discomfort. Major potential morbidities include additional surgery, meningitis, and tension pneumocephalus. Postoperative meningitis rate increases from $0.3 \%$ to $3 \%$ in cases with LD perioperative usage. The current literature does not provide conclusive evidence that lumbar drainage during pituitary surgery decreases postoperative CSF leaks; however, its use during pituitary surgery is safe and can beneficial in selected cases.
\end{abstract}

Keywords: Perioperative Cerebrospinal fluid; Lumbar drains; CSF diversion; Transsphenoidal surgery; Pituitary surgery

\section{Introduction}

Transsphenoidal pituitary surgery is a common surgical procedure that has now been accepted as the standard approach to sellar lesions [1]. Transsphenoidal surgery has been repeatedly reported as a safe and effective method for pituitary tumor resection; however, it is not without risks and potential complications [2-5]. Persistent postoperative cerebrospinal fluid (CSF) leakage is a major cause of morbidity following transsphenoidal surgery for pituitary adenomas [2,6-8]. A national study, examining complications of transsphenoidal surgery, cites the incidence of postoperative CSF leak to be $3.9 \%$ [9]. With the introduction of the nasoseptal flap, the incidence of CSF leaks has significantly decreased after transsphenoidal surgery [10]. Although this procedure has reduced the incidence, it has not completely eliminated postoperative CSF leaks. Lumbar drains (LD) for perioperative CSF diversion can be utilized as a prophylactic measure and/or as a first line treatment for CSF rhinorrhea following transsphenoidal pituitary surgery. Lumbar drainage has been considered as a safe and effective treatment for CSF rhinorrhea following transsphenoidal surgery; however, this was not validated in prospective studies. We hypothesize that perioperative LD CSF diversion reduces the incidence of postoperative CSF leaks. In this report, we study the value of perioperative $\mathrm{LD}$ and also review the current literature discussing LD usage methodology, CSF diversion indications, reported complication, and reported algorithms.

\section{Methods}

We performed a Pubmed search for studies that looked at postoperative CSF leak rates following transsphenoidal surgery in relation to perioperative LD CSF diversion. Specifically, we searched for the following key words: CSF, Lumbar Drains, CSF diversion, Transsphenoidal Surgery, and pituitary surgery. The inclusion criteria were based on number of patients in each study and how recent the study was published. We analyzed data published from centers with significant experience with transsphenoidal surgery. We found a total of 16 studies which fit our criteria. All of the studies had volumes greater than 100. We only included studies after the year 2000. All extracted data was tabulated into an excel spreadsheet. Information on tumor type, number of patients, percent of postoperative rhinorrhea cases, number of LDs used, indication for LD usage, average length of LD use, length of stay in hospital, and complications of LD use were analyzed for each study. We analyzed the conglomerate rate of CSF leak from the included studies as well as analyzed how often LDs are used in the setting of CSF leaks. The statistical significance of preventing CSF leak with the use of LDs could not be calculated because there are no comparison control studies without LD usage.

\section{Results}

We looked at a total of 6,401 patients who underwent transsphenoidal surgery for sellar tumors from 16 different studies (Table 1). The overall incidence of postoperative CSF rhinorrhea was $1.7 \%$. Out of 6,401 patients, 385 patients $(6 \%)$ received a LD perioperatively. The statistical significance of preventing CSF leak with the use of LDs could not be calculated as there are no comparison control studies without LD usage. Although not all papers published complications, there were at least 19 documented major complications. 18 patients developed meningitis (0.3\%); LD use was documented in 12 cases. The rate of developing meningitis in the 385 cases with LD use was $3 \%$. In one patient, the lumbar drain catheter broke leaving retained catheter in the lumbar cistern. There is great variability among the different studies as to which patients received a $\mathrm{LD}$, and each

*Corresponding author: Abdulrazag Ajlan, Neurosurgery Department, Stanford University, Stanford, USA, Tel: 6508393087; E-mail: dr_ajlan79@hotmail.com

Received January 17, 2014; Accepted March 12, 2014; Published March 15 2014

Citation: Jung H, Shah A, Ajlan A (2014) Perioperative Cerebrospinal Fluid Diversion Utilizing Lumbar Drains in Transsphenoidal Surgery. J Neurol Disord 2: 150. doi:10.4172/2329-6895.1000150

Copyright: (c) 2014 Jung $\mathrm{H}$, et al. This is an open-access article distributed under the terms of the Creative Commons Attribution License, which permits unrestricted use, distribution, and reproduction in any medium, provided the original author and source are credited. 
Citation: Jung H, Shah A, Ajlan A (2014) Perioperative Cerebrospinal Fluid Diversion Utilizing Lumbar Drains in Transsphenoidal Surgery. J Neurol Disord 2: 150. doi:10.4172/2329-6895.1000150

Page 2 of 6

\begin{tabular}{|c|c|c|c|c|c|c|c|c|c|c|}
\hline $\begin{array}{l}\text { Study } \\
\text { author, year } \\
\text { (Citation) }\end{array}$ & $\begin{array}{l}\text { Tumor } \\
\text { Type }\end{array}$ & $\begin{array}{l}\text { Total } \\
\text { number of } \\
\text { patients }\end{array}$ & $\begin{array}{l}\text { Post-operative } \\
\text { Rhinorrhea } \\
\text { n (\%) }\end{array}$ & $\begin{array}{l}\text { LD for } \\
\text { postop } \\
\text { CSF leak }\end{array}$ & $\begin{array}{l}\text { Periop LD } \\
\text { to prevent } \\
\text { postop leak* }\end{array}$ & $\begin{array}{l}\text { Average } \\
\text { length of LD } \\
\text { use (days) }\end{array}$ & $\begin{array}{l}\text { Length of Stay } \\
\text { in Hospital of } \\
\text { with LD (Days) }\end{array}$ & $\begin{array}{l}\text { Complication } \\
\text { of patients } \\
\text { with LD }\end{array}$ & Comments & Indications \\
\hline $\begin{array}{l}\text { Seiler } \\
\text { et al. [13] }\end{array}$ & All tumors & 376 & $2(0.5 \%)$ & 8 & Unclear & 2 to 3 & 3 to 5 & - & - & $\begin{array}{l}\text { In macroadenomas } \\
\text { and large intraoperative } \\
\text { tears of the diaphragm } \\
\text { or postoperative CSF } \\
\text { leak }\end{array}$ \\
\hline $\begin{array}{l}\text { Nasseri } \\
\text { et al. [21] }\end{array}$ & $\begin{array}{l}\text { All } \\
\text { adenomas }\end{array}$ & 180 & $6(3.3 \%)$ & 2 & Not used & 7 & - & - & - & $\begin{array}{l}\text { Only for postoperative } \\
\text { leak }\end{array}$ \\
\hline $\begin{array}{l}\text { Cappabiance } \\
\text { et al. [17] }\end{array}$ & $\begin{array}{l}\text { All } \\
\text { adenomas }\end{array}$ & 170 & $4(3.3 \%)$ & 1 & 2 & 5 & - & - & - & $\begin{array}{l}\text { In cases with } \\
\text { intraoperative CSF } \\
\text { leak, or if the closure } \\
\text { was not watertight, or } \\
\text { postoperative CSF leak }\end{array}$ \\
\hline $\begin{array}{l}\text { Zada et al. } \\
\text { [3] }\end{array}$ & All tumors & 109 & $3(3 \%)$ & 4 & 8 & 2 to 3 & - & $\begin{array}{l}2 \text { Cases of } \\
\text { Meningitis }\end{array}$ & - & $\begin{array}{l}\text { For very large } \\
\text { diaphragmatic openings, } \\
\text { or for postoperative } \\
\text { CSF leaks }\end{array}$ \\
\hline $\begin{array}{l}\text { Shiley et al. } \\
\text { [11] }\end{array}$ & All tumors & 235 & $13(6 \%)$ & 11 & Not used & $>3$ & - & & - & $\begin{array}{l}\text { Only for postoperative } \\
\text { CSF leak }\end{array}$ \\
\hline $\begin{array}{l}\text { Cappabiance } \\
\text { et al. [24] }\end{array}$ & All tumors & 242 & $5(2.1 \%)$ & 2 & 7 & - & - & & $\begin{array}{l}\text { Two out of } 7 \\
\text { LD used for } \\
\text { postop } \\
\text { drainage }\end{array}$ & $\begin{array}{l}\text { In cases with copious } \\
\text { intraoperative CSF } \\
\text { leak, if the closure } \\
\text { was not watertight, } \\
\text { in postoperative CSF } \\
\text { leak, or cases of } \\
\text { extended approach. }\end{array}$ \\
\hline $\begin{array}{l}\text { Van Aken } \\
\text { et al. [34] }\end{array}$ & All tumors & 278 & $3(1.1 \%)$ & - & 70 & $>5$ & - & $\begin{array}{l}1 \text { Case of } \\
\text { Meningitis }\end{array}$ & $\begin{array}{l}3 \text { out of } 22 \\
\text { patients who } \\
\text { had no LD in- } \\
\text { sertion despite } \\
\text { having introp } \\
\text { CSF leak } \\
\text { developed } \\
\text { meningitis } \\
\text { (previous } \\
\text { cohort) }\end{array}$ & $\begin{array}{l}\text { If intraoperative CSF } \\
\text { leak is observed }\end{array}$ \\
\hline $\begin{array}{l}\text { Mortini } \\
\text { et al. [5] }\end{array}$ & $\begin{array}{l}\text { All } \\
\text { adenomas }\end{array}$ & 1140 & $4(0.3 \%)$ & 1 & Unclear & 5 & - & $\begin{array}{l}1 \text { Case of } \\
\text { Meningitis }\end{array}$ & $\begin{array}{l}\text { In all cases, } \\
\text { under general } \\
\text { anesthesia, a } \\
\text { lumbar needle } \\
\text { is placed to } \\
\text { allow both the } \\
\text { intraoperative } \\
\text { drainage of } \\
\text { cerebrospinal } \\
\text { fluid and the } \\
\text { injection of } \\
\text { air into the } \\
\text { subarachnoid } \\
\text { space }\end{array}$ & $\begin{array}{l}\text { In cases of large CSF } \\
\text { intraoperative leaks }\end{array}$ \\
\hline $\begin{array}{l}\text { Nishioka } \\
\text { et al. [6] }\end{array}$ & All tumors & 200 & $5(2.5 \%)$ & 3 & Not used & - & - & - & - & $\begin{array}{l}\text { Only for postoperative } \\
\text { CSF leak }\end{array}$ \\
\hline $\begin{array}{l}\text { Sade } \\
\text { et al. [12] }\end{array}$ & All tumors & 127 & $2(1.6 \%)$ & - & 61 & 3 & 4 & $\begin{array}{l}2 \text { Cases of } \\
\text { Meningitis }\end{array}$ & - & $\begin{array}{l}\text { LD was inserted } \\
\text { before the procedure if } \\
\text { intraop CSF leak was } \\
\text { expected or if saline } \\
\text { infusion was planned. } \\
\text { LD was inserted at } \\
\text { the end of the case if } \\
\text { intraop CSF leak was } \\
\text { observed. }\end{array}$ \\
\hline $\begin{array}{l}\text { Seda } \\
\text { et al. [7] }\end{array}$ & All tumors & 567 & $1(0.1 \%)$ & - & 64 & 5 & 1 & $\begin{array}{l}1 \text { Case of } \\
\text { Meningitis }\end{array}$ & - & $\begin{array}{l}\text { If intraoperative CSF } \\
\text { leak is observed }\end{array}$ \\
\hline $\begin{array}{l}\text { Fatemi } \\
\text { et al. [1] }\end{array}$ & All tumors & 812 & $19(2 \%)$ & 4 & Unknown & 2 & - & $\begin{array}{l}3 \text { Cases of } \\
\text { Meningitis }\end{array}$ & $\begin{array}{l}2 \text { of the } \\
\text { meningitis } \\
\text { cases had } \\
\text { extended } \\
\text { approach }\end{array}$ & $\begin{array}{l}\text { If intraoperative CSF } \\
\text { leak is observed } \\
\text { (grade \#3), or for } \\
\text { postoperative CSF } \\
\text { leak }\end{array}$ \\
\hline
\end{tabular}




\begin{tabular}{|c|c|c|c|c|c|c|c|c|c|c|}
\hline $\begin{array}{l}\text { Han et al. } \\
{[16]}\end{array}$ & Macroadenomas & 592 & $26(4.4 \%)$ & 20 & 26 & 5 to 7 & - & $\begin{array}{l}5 \text { Cases of } \\
\text { Meningitis, } \\
\text { one required } \\
\text { shunting } \\
\text { (unclear how } \\
\text { many had LD) }\end{array}$ & $\begin{array}{l}12 \text { patients out } \\
\text { of } 20 \text { postop } \\
\text { leaks were } \\
\text { managed } \\
\text { successfully } \\
\text { with LD only }\end{array}$ & $\begin{array}{l}\text { If large intraoperative } \\
\text { CSF leakage is } \\
\text { observed (definite } \\
\text { diaphragmatic defect, } \\
\text { which could not be } \\
\text { controlled by bipolar } \\
\text { coagulation or large } \\
\text { diaphragmatic/dural } \\
\text { defect }\end{array}$ \\
\hline $\begin{array}{l}\text { Hobbs et } \\
\text { al. [8] }\end{array}$ & All adenomas & 120 & $2(1.7 \%)$ & Not used & Not used & - & - & - & $\begin{array}{l}\text { One patient } \\
\text { required } \\
\text { shunting }\end{array}$ & $\begin{array}{l}\text { They avoid the use of } \\
\text { LD for perioperative } \\
\text { management }\end{array}$ \\
\hline $\begin{array}{l}\text { Kaptain et } \\
\text { al. } 2011(20)\end{array}$ & All tumors & 1095 & $6(0.6 \%)$ & 2 & 39 & 3 & $\begin{array}{l}4.2 \text { with no leak, } \\
16.6 \text { with po- } \\
\text { stop CSF leak }\end{array}$ & $\begin{array}{l}3 \text { Cases of } \\
\text { meningitis ( } 2 \\
\text { with LD) }\end{array}$ & - & $\begin{array}{l}\text { In tumors with } \\
\text { suprasellar extension } \\
\text { to facilitate tumor } \\
\text { resection. Catheters } \\
\text { were maintained } \\
\text { selectively in the } \\
\text { postop to prevent } \\
\text { rhinorrhea }\end{array}$ \\
\hline $\begin{array}{l}\text { Mehta et al. } \\
2012(26)\end{array}$ & Macroadenomas & 158 & $8(5 \%)$ & 6 & 44 & $\begin{array}{l}\text { If no leak at } \\
\text { end of case, } \\
\text { LD was } \\
\text { removed }\end{array}$ & - & $\begin{array}{l}\text { In one case } \\
\text { the LD cath- } \\
\text { eter broke in } \\
\text { the intrathecal } \\
\text { space }\end{array}$ & $\begin{array}{l}\text { Looked at the } \\
\text { prevention of } \\
\text { intraoperative } \\
\text { CSF leak by } \\
\text { LD insertion } \\
\text { during surgery, } \\
\text { this was } \\
\text { reduced but } \\
\text { postop leak } \\
\text { was the same }\end{array}$ & $\begin{array}{l}\text { Routine LD use for } \\
\text { transsphenoidal } \\
\text { resection of } \\
\text { macroadenomas. }\end{array}$ \\
\hline Total & & 6401 & $109(1.7 \%)$ & 64 & 321 & & & & & \\
\hline
\end{tabular}

*Includes perioperative use to prevent postoperative CSF leak and to facilitate tumor resection. Lumbar drains inserted before the surgery after intubation or after the surgery.

Table 1: Transsphenoidal surgeries and CSF leaks. Preoperative (preop), postoperative (postop), perioperative (periop), lumbar drains (LD), cerebrospinal fluid (CSF).

surgeon has his/her personalized strategy for preventing or treating CSF leaks (Table 1).

\section{Discussion}

\section{Risk factors of cerebrospinal fluid leak}

Various studies have investigated the factors that contribute to persistent CSF leak [2,11-13]. Black et al. reported a higher incidence of postoperative CSF leak in macroadenomas (4.2\%), particularly those with suprasellar extension, than microadenomas $(0.9 \%)$. On the other hand, others did not observe any correlation between pituitary adenoma size and the likelihood of postoperative leak [13].

Other reported risk factors for CSF leak include revision transsphenoidal surgery, nonadenomatous disease, and presence of intraoperative leak. With presence of scar tissue, adhesions, displaced vascularity, or distorted anatomy, revision surgery renders dissection more difficult. As revision surgery usually occurs to remove tumor that was not easily accessible in the first surgery, it can often involve aggressive dissection along the diaphragma sellae which places the patient in greater risk for CSF leak. Postoperative CSF leaks are more commonly seen when a visible CSF leak is seen during surgery than when a leak is not seen intraoperatively $(2.9 \%$ vs $0.0 \%)$ [13]. Furthermore, intraoperative CSF leak has an average incidence of approximately $40 \%$ $[3,11,14,15]$. Surgery on ACTH adenomas was reported to have higher incidence of intraoperative and postoperative CSF leaks [16]. The margins of the tumor and the consistency of the adenoma were also found to be significant risk factors for intraoperative CSF leaks [16].

\section{Management of CSF leaks}

Given the complication of persistent CSF leak, various strategies have been developed to repair CSF leaks. For example, various methods for sellar floor repair have been devised [17-21]. The nasoseptal flap has significantly reduced the incidence of CSF leaks [10]. If a postoperative leak is present, some authors advocate a trial of non-operative treatment with lumbar drainage for 3 or more days $[9,22]$. Lumbar drainage is used to divert CSF flow away from the sellar defect [12]. This allows for the initial healing of the reconstructed skull-base and reduces the likelihood of recurrent CSF fistula. Others advocate immediate reexploration with repacking of the sellae and sphenoid $[2,11]$. Laws et al. stress the ease and efficacy of re-exploration and contends that lumbar drainage is often uncomfortable and stressful for patients and usually fails in treating CSF leaks [23]. Certainly, one of the advantages of early re-exploration is the avoidance of prolonged hospitalization for patients who require surgery after failing a lumbar drain trial. Given the high success rate with endoscopic management, Seiley et al. favor early re-exploration [13]. In the setting of post-infectious hydrocephalus, ventriculoperitoneal shunting may also be warranted $[11,16]$.

\section{Indications}

Although the LD has been utilized for various reasons, there are no guidelines for LD use in transsphenoidal surgery. As of now, LD usage is determined by the center of care. Preoperatively, LDs assist in delivering the suprasellar portions to be surgically accessible in cases of macroadenomas, especially in cases where the sellae is small or when there is a bottleneck constriction at the diaphragm level [23]. Other authors may insert a LD preoperatively as they may anticipate CSF leak postoperatively [24].

Postoperatively, the LD is routinely used to divert CSF flow to prevent or treat CSF rhinorrhea. Schwartz et al. constructed an 
algorithm for sellar reconstruction after endoscopic pituitary surgery. They currently avoid using a drain preoperatively for most procedures and only consider it in patients with large encephaloceles and highvolume CSF leaks preoperatively, in patients with large anterior skull base lesions such as meningiomas, and in cases of anticipated patient comorbidities including increased intracranial pressure [25]. In their study, all patients with postoperative CSF leak underwent lumbar drainage for 3-5 days with high success rates of closure without operative re-exploration [25]. On the other hand, Mehta et al. purport that lumbar drainage can reduce intraoperative CSF leak, and they frequently place LDs preoperatively [26].

\section{Timing}

The timing of placement of the LD cannot be generalized. Some surgeons place them before surgery and others place them postoperatively only in the setting of a postoperative CSF leak. Furthermore, with the LDs that were placed prior to surgery, there is usually no mention of whether the LD was placed in the preoperative area or placed after the patient was already sedated and intubated. Placing a LD in an intubated patient has a theoretical risk of injuring a nerve root or causing a spinal hematoma which would otherwise not be detected early. On the other hand, placement of LDs are painful to patients so many surgeons may prefer to place them after patient sedation. Most studies did not specify when the lumbar drain was placed; however, some exceptions include Mehta et al. who reported the placement of the LD prior to surgery after patient intubation and Ransom et al. who placed the LD prospectively during the time of surgery. Both reported no neurological deficits related to the LD insertion $[26,27]$. On the other hand, other authors never use LDs for the purpose of preventing or anticipating CSF leak, and only place LDs postoperatively if a CSF leak is seen [23]. However, Laws et al. may place a LD preoperatively if the LD is used to assist in delivering the suprasellar portions of a macroadenoma [23]. As of yet, there is no consensus on the timing of when a lumbar drain should be placed.

\section{Treating postoperative leaks}

In regards to the efficacy of LD CSF diversion in treating postoperative CSF leaks, it is generally considered an effective treatment for CSF rhinorrhea in more than half the cases. Findler et al. and Shapiro et al. reported success rates of $84 \%$ and $94 \%$, respectively, in treating CSF rhinorrhea $[28,29]$. However, Han et al. retrospectively looked at 592 patients with macroadenomas, and of 26 patients that had a postoperative CSF leak, only 12 out of 20 patients treated with lumbar drainage were successfully treated (60\% success rate) [16].

\section{Advantages}

The main advantage of conservative treatment with lumbar drainage is that it avoids re-exploration surgery and the associated complications. Thus, overall, the use of LDs may also be cost effective. If re-exploration becomes necessary in patients with $\mathrm{LDs}$, intrathecal fluorescein can be used to help identify the site of CSF leak or to confirm adequate repair. Another possible advantage of lumbar drainage is that it may be used to reduce the incidence of intraoperative leak. One study by Mehta et al. endeavored to reduce the rate of intraoperative CSF leakage by placement of a lumbar drain prior to surgery and draining 20-60 $\mathrm{ml}$ of CSF as the pituitary tumor was removed [26]. They compared 114 transsphenoidal operations for pituitary macroadenomas without the use of intraoperative CSF drainage to 44 cases with the use of lumbar drainage. They reported a reduction in the rate of intraoperative CSF leakage from $41 \%$ to $5 \%$. However, the rate of postoperative CSF leakage was similar at 5\%. Furthermore, intraoperative CSF drainage reduced the need for operative repair from $32 \%$ to $5 \%$. Thus, they posit that intraoperative CSF drainage with a LD can obviate the need for sellar defect repair or additional surgical repair of CSF leak observed intraoperatively [30]. Moreover, sellar floor repair has its own associated morbidity and expense. The authors hypothesize that intraoperative drainage of CSF reduces tension on the arachnoid rendering it less likely to rupture.

Laws et al. counter the study by Mehta and Oldfield [23]. They use the lumbar drain sparingly; of 356 transsphenoidal operations, they used LDs only seven times. Furthermore, their experience regarding the risks of lumbar drainage differs from Mehta and Oldfield. They cite experiences of symptomatic intractable post-lumbar puncture headache, radiculopathies, and retained fragments of lumbar drain catheter. These complications have led to prolonged hospital stays, need for blood patches, and laminectomy surgery to remove retained fragments.

\section{Complications of lumbar drain}

Despite the moderate success rates seen with lumbar drainage, there is, unfortunately, a pervasive absence of level I data supporting lumbar drain usage. Despite the paucity of such information, there is much literature on the potential deleterious ramifications of LD usage. The absence of clear evidence supporting LD diversion in pituitary surgery should be always kept in mind during decision making and before LD insertion. The complication rate has been shown to be low for LD procedures, though the complications themselves vary in terms of severity [31]. The relatively minor complications include headache; however, there have been much more severe ramifications described such as cerebral herniation, pneumocephalus, and meningitis [3234]. Many inherent risks for lumbar drainage procedures may be overlooked. These include infections such as cellulitis and meningitis, headache, and retained catheter fragments [35]. The overall infection rates, including superficial skin infection, have been reported to be around $10 \%$ for lumbar drainage [28,32]. Understanding the complications of LDs is essential to decrease related morbidity and healthcare utilization and costs [30].

\section{Minor complications}

Headaches, although not life threatening, are the most common complaint causing discomfort. Kitchel et al. reported a 58\% incidence rate for transient headache during active drainage which is similar to the $63 \%$ incidence rate reported by Shapiro et al. $[28,36]$. Headache following lumbar drainage is thought to occur from a constant leakage of CSF into the soft tissue of the lower back [30]. Symptoms manifest from intrathecal hypotension. Symptoms may resolve in 48 hours or may persist for one or more weeks [37]. With such prolonged symptoms, an epidural blood patch may be necessary which involves the injection of 5-10 cc of the patient's own blood into the epidural space so that the resulting clot can plug the hole in the dura [30]. Although there is no substantial evidence for the use of a prophylactic blood patch, the blood patch has been demonstrated to be effective [29]. It was suggested that changing the rate of CSF drainage, intravenous hydration, and medication are all effective in treating headache [32]. Fracture of the LD catheter is yet another potential complication which may occur during removal. This complication is generally seen in cases when there is difficulty in lumbar drain placement requiring multiple punctures [38]. Conservative management and observation is indicated unless the fragment results in pain or neurological deficits [26]. The resulting operation for removal adds significantly to morbidity and 
resource utilization [39]. Often, follow up imaging of the lumbar spine is ordered to corroborate complete removal.

\section{Major complications}

Accidental overdrainage is a significant contributor to complications with lumbar drains. The changes in drainage flow rate may lead to pneumocephalus, subdural hemorrhage, neurological decline, or uncal herniation [35]. Graf et al. reported three cases of neurological changes caused by tension pneumocephalus. These patients were initially treated with continuous lumbar spinal drainage to alleviate a CSF fistula; however, over drainage occurred causing pneumocephalus [40]. They suggest that a negative pressure gradient (caused by head elevation and spinal drainage) between the atmospheric pressure gradient and intracranial pressure caused a siphon effect that led to air entering the intracranial space through the fistula. Others also report of a few cases of over drainage due to an error in chamber placement causing pneumocephalus [28]. As a result, some propose that the rate of drainage should not exceed 5-10 ml/hour (normal adult CSF production is approximately $20 \mathrm{ml} / \mathrm{h}$ ), thereby eliminating a pressure gradient that could lead to pneumocephalus [32]. In this setting, pneumocephalus occurrence is usually associated with communication with an air sinus [28].

Although it well known that lumbar drainage can have severe ramifications in the setting of increased intracranial pressure, it is not known how often lumbar drainage produces tentorial herniation. Two reported cases of herniation after intraoperative lumbar drainage recovered with the use of an epidural blood patch [41]. In another documented case of transtentorial herniation following LD [18], the patient was able to follow commands after the LD was clamped for eight hours. Thus, they suggested that the removal of CSF below the tentorium augmented the pressure gradient between the supratentorial and lumbar cistern promoting tentorial herniation [42]. Pneumocephalus enhanced this pressure gradient encouraging the herniation which was observed clinically.

The risk of developing postoperative CSF infection was low at $0.3 \%$ in the analyzed group $(n=6401)$. This risk increased to $3 \%$ in cases with LD usage. This association can be either a direct result of introducing a foreign body into the subarachnoid space or it can be a result of the higher number of CSF leaks in the cohort of cases with LD use. The use of antibiotics did not decrease the risk of infection. One case out of 12 cases of meningitis required Ventriculoperitoneal shunt insertion.

Another contributor for complications lies in personal error: either mishandling of the lumbar drain or miscommunication for choosing an open versus closed position [30]. While these errors can be minimized, this may be representative of the errors that can take place when multiple patient-care transfers are involved. Unintended disconnection, inadvertent opening, and overdrainage are recurrently seen [30]. Lumbar drain complications may occur in a variety of cases irrespective of the reason for placement; limiting the use of LDs is the only way to reliably reduce the associated morbidity.

\section{Length of stay}

Another disadvantage of LD diversion is that a failed trial of drainage may extend the length of hospitalization and the length of time a patient may have CSF rhinorrhea. This must then be repaired via surgical re-exploration. Postoperative stay can be significantly longer in patients with CSF leak. In fact, one study reported the mean hospitalization stay for patients with a CSF leak to be $5.4 \pm 2.2$ days, and the mean stay for patients without a leak to be $3.5 \pm 1.9$ days [11]. After including the additional admissions secondary to the complications of CSF leak, the difference was extended to $14.9 \pm 13.5$ days in the CSF leak group versus $3.5 \pm 1.9$ days in the non-leak group [11]. While complications increase healthcare costs, the presence of a lumbar drain alone increases resource utilization by adding extra hospital days, laboratory studies, and/or imaging procedures [43]. Thus, lumbar drains should be utilized prudently.

\section{Conclusion}

Lumbar drains are commonly used for perioperative CSF diversion as a prophylactic measure and/or as first line treatment for CSF rhinorrhea following transsphenoidal pituitary surgery. The risk of complication with the use of lumbar drains is low. Although generally considered safe, LD insertion increases the length of hospitalization. Minor complications include headaches and patient discomfort. Postoperative meningitis rate increases from $0.3 \%$ to $3 \%$ in cases with LD perioperative usage. Rare major potential morbidities include additional surgery and tension pneumocephalus. Although it is commonly suggested that perioperative LD insertion for CSF diversion decreases the overall risk of postoperative CSF leaks, this was not validated with high quality prospective studies.

\section{References}

1. Fatemi N, Dusick JR, de Paiva Neto MA, Kelly DF (2008) The endonasal microscopic approach for pituitary adenomas and other parasellar tumors: a 10-year experience. Neurosurgery 63: 244-256.

2. Black PM, Zervas NT, Candia GL (1987) Incidence and management of complications of transsphenoidal operation for pituitary adenomas. Neurosurgery 20: 920-924.

3. Zada G, Kelly DF, Cohan P, Wang C, Swerdloff R (2003) Endonasal transsphenoidal approach for pituitary adenomas and other sellar lesions: an assessment of efficacy, safety, and patient impressions. J Neurosurg 98: 350-358.

4. Benveniste RJ, King WA, Walsh J, Lee JS, Delman BN, et al. (2005) Repeated transsphenoidal surgery to treat recurrent or residual pituitary adenoma. J Neurosurg 102: 1004-1012.

5. Mortini P, Losa M, Barzaghi R, Boari N, Giovanelli M (2005) Results of transsphenoidal surgery in a large series of patients with pituitary adenoma. Neurosurgery 56: 1222-1233.

6. Nishioka H, Haraoka J, Ikeda Y (2005) Risk factors of cerebrospinal fluid rhinorrhea following transsphenoidal surgery. Acta Neurochir (Wien) 147: 1163-1166.

7. Seda L, Camara RB, Cukiert A, Burattini JA, Mariani PP (2006) Sellar floor reconstruction after transsphenoidal surgery using fibrin glue without grafting or implants: technical note. Surgical neurology 66: 46-49; discussion 49.

8. Hobbs CG, Darr A, Carlin WV (2011) Management of intra-operative cerebrospinal fluid leak following endoscopic trans-sphenoidal pituitary surgery. J Laryngol Otol 125: 311-313.

9. Ciric I, Ragin A, Baumgartner C, Pierce D (1997) Complications of transsphenoidal surgery: results of a national survey, review of the literature and personal experience. Neurosurgery 40: 225-236.

10. Kassam AB, Thomas A, Carrau RL, Snyderman CH, Vescan A, et al. (2008) Endoscopic reconstruction of the cranial base using a pedicled nasoseptal flap. Neurosurgery 63: ONS44-52.

11. Shiley SG, Limonadi F, Delashaw JB, Barnwell SL, Andersen PE, et al. (2003) Incidence, etiology, and management of cerebrospinal fluid leaks following trans-sphenoidal surgery. Laryngoscope 113: 1283-1288.

12. Sade B, Mohr G, Frenkiel S (2006) Management of intra-operative cerebrospinal fluid leak in transnasal transsphenoidal pituitary microsurgery: use of post-operative lumbar drain and sellar reconstruction without fat packing. Acta neurochirurgica 148: 13-18.

13. Seiler RW, Mariani L (2000) Sellar reconstruction with resorbable vicryl patches, gelatin foam, and fibrin glue in transsphenoidal surgery: a 10-year experience with 376 patients. J Neurosurg 93: 762-765.

14. Kelly DF, Oskouian RJ, Fineman I (2001) Collagen sponge repair of smal 
Citation: Jung H, Shah A, Ajlan A (2014) Perioperative Cerebrospinal Fluid Diversion Utilizing Lumbar Drains in Transsphenoidal Surgery. J Neurol Disord 2: 150. doi:10.4172/2329-6895.1000150

Page 6 of 6

cerebrospinal fluid leaks obviates tissue grafts and cerebrospinal fluid diversion after pituitary surgery. Neurosurgery 49: 885-889; discussion 889 890.

15. Kirtane MV, Gautham K, Upadhyaya SR (2005) Endoscopic CSF rhinorrhea closure: our experience in 267 cases. Otolaryngol Head Neck Surg 132: 208-212.

16. Han ZL, He DS, Mao ZG, Wang HJ (2008) Cerebrospinal fluid rhinorrhea following trans-sphenoidal pituitary macroadenoma surgery: experience from 592 patients. Clinical neurology and neurosurgery 110: 570-579.

17. Cappabianca P, Cavallo LM, Esposito F, Valente V, De Divitiis E (2002) Sellar repair in endoscopic endonasal transsphenoidal surgery: results of 170 cases. Neurosurgery 51: 1365-1371.

18. Esposito F, Dusick JR, Fatemi N, Kelly DF (2007) Graded repair of cranial base defects and cerebrospinal fluid leaks in transsphenoidal surgery. Neurosurgery 60: 295-303

19. Couldwell WT, Kan P, Weiss MH (2006) Simple closure following transsphenoidal surgery. Technical note. Neurosurg Focus 20: E11.

20. Kaptain GJ, Kanter AS, Hamilton DK, Laws ER (2011) Management and implications of intraoperative cerebrospinal fluid leak in transnasoseptal transsphenoidal microsurgery. Neurosurgery 68(1 Suppl Operative): 144-150.

21. Nasseri SS, Kasperbauer JL, Strome SE, McCaffrey TV, Atkinson JL, et al. (2001) Endoscopic transnasal pituitary surgery: report on 180 cases. Am J Rhinol 15: 281-287.

22. Kelley TF, Stankiewicz JA, Chow JM, Origitano TC, Shea J (1996) Endoscopic closure of postsurgical anterior cranial fossa cerebrospinal fluid leaks. Neurosurgery 39: 743-746

23. Laws ER Jr, de Los Reyes K, Rincon-Torroella J (2013) Lumbar drains in transsphenoidal surgery. J Neurosurg 118: 480-481.

24. Cappabianca P, Cavallo LM, Valente V, Romano I, D'Enza Al, et al. (2004) Sellar repair with fibrin sealant and collagen fleece after endoscopic endonasal transsphenoidal surgery. Surg Neurol 62: 227-233.

25. Tabaee A, Anand VK, Brown SM, Lin JW, Schwartz TH (2007) Algorithm for reconstruction after endoscopic pituitary and skull base surgery. Laryngoscope 117: 1133-1137.

26. Mehta GU, Oldfield EH (2012) Prevention of intraoperative cerebrospinal fluid leaks by lumbar cerebrospinal fluid drainage during surgery for pituitary macroadenomas. J Neurosurg 116: 1299-1303.

27. Ransom ER, Chiu AG (2010) Prevention and management of complications in intracranial endoscopic skull base surgery. Otolaryngol Clin North Am 43 875-895.

28. Shapiro SA, Scully T (1992) Closed continuous drainage of cerebrospinal fluid via a lumbar subarachnoid catheter for treatment or prevention of cranial/ spinal cerebrospinal fluid fistula. Neurosurgery 30: 241-245.

29. Findler G, Sahar A, Beller AJ (1977) Continuous lumbar drainage of cerebrospinal fluid in neurosurgical patients. Surg Neurol 8: 455-457.

30. Ransom ER, Palmer JN, Kennedy DW, Chiu AG (2011) Assessing risk/benefit of lumbar drain use for endoscopic skull-base surgery. Int Forum Allergy Rhinol 1: 173-177.

31. Barrow DL, Tindall GT (1990) Loss of vision after transsphenoidal surgery. Neurosurgery 27: 60-68.

32. Açikbaş SC, Akyüz M, Kazan S, Tuncer R (2002) Complications of closed continuous lumbar drainage of cerebrospinal fluid. Acta Neurochir (Wien) 144 475-480.

33. Casiano RR, Jassir D (1999) Endoscopic cerebrospinal fluid rhinorrhea repair: is a lumbar drain necessary? Otolaryngol Head Neck Surg 121: 745-750.

34. van Aken MO, Feelders RA, de Marie S, van de Berge $\mathrm{JH}$, Dallenga $\mathrm{AH}$ et al. (2004) Cerebrospinal fluid leakage during transsphenoidal surgery: postoperative external lumbar drainage reduces the risk for meningitis. Pituitary 7: 89-93.

35. Francel PC, Persing JA, Cantrell RW, Levine PA, Newman SA (1992) Neurological deterioration after lumbar cerebrospinal fluid drainage. J Craniofac Surg 3: 145-148.

36. Kitchel SH, Eismont FJ, Green BA (1989) Closed subarachnoid drainage for management of cerebrospinal fluid leakage after an operation on the spine. $J$ Bone Joint Surg Am 71: 984-987.

37. Boonmak P, Boonmak S (2010) Epidural blood patching for preventing and treating post-dural puncture headache. The Cochrane database of systematic reviews.

38. Forsythe A, Gupta A, Cohen SP (2009) Retained intrathecal catheter fragment after spinal drain insertion. Reg Anesth Pain Med 34: 375-378.

39. Olivar H, Bramhall JS, Rozet I, Vavilala MS, Souter MJ, et al. (2007) Subarachnoid lumbar drains: a case series of fractured catheters and a near miss. Can J Anaesth 54: 829-834.

40. Graf CJ, Gross CE, Beck DW (1981) Complications of spinal drainage in the management of cerebrospinal fluid fistula. J Neurosurg 54: 392-395.

41. Guido LJ, Patterson RH Jr (1976) Focal neurological deficits secondary to intraoperative CSF drainage: successful resolution with an epidural blood patch. Report of two cases. J Neurosurg 45: 348-351.

42. Snow RB, Kuhel W, Martin SB (1991) Prolonged lumbar spinal drainage after the resection of tumors of the skull base: a cautionary note. Neurosurgery 28 880-882.

43. Leong JL, Citardi MJ, Batra PS (2006) Reconstruction of skull base defects after minimally invasive endoscopic resection of anterior skull base neoplasms. Am J Rhinol 20: 476-482. 